GLOBAL JOURNAL OF SOCIAL SCIENCES VOL 20, 2021: 77-85

COPYRIGHT@ BACHUDO SCIENCE CO. LTD PRINTED IN NIGERIA. ISSN 1596-6216

\title{
CASTE CONFLICT IN NIGERIA: THE OSUIDIALA EXPERIENCE IN IGBOLAND, 1900-2017
}

NNEKA SOPHIE AMALU, YUSUF ABDULLAHI AND EKONG DEMSON

(Received 5 February 2021, Revision Accepted 12 April 2021)

\begin{abstract}
The paper seeks to examine caste conflict in Nigeria with particular focus on the Osu/Diala experience. In Nigeria every day we experience conflicts ranging from ethnic to religious, sects to caste conflicts, while so much attention is paid to other types of conflict, little attention has been paid to the conflicts between caste group. This could be the reason for paucity of literature on caste conflicts in Nigeria. The frustration-aggression theory is used as framework of analysis with qualitative descriptive research design and a multi-disciplinary approach of historical study as methodology. The Igbo since time immemorial have been divided majorly along lines of caste with the Diala perceived to be the superior and the Osu the inferior. This division comes with some political, economic, social and cultural restrictions for the Osu caste in communities where the system is practiced. Consequently, these restrictions breed anger, hatred, anxiety, tension, frustration and aggression as the Osu continually demand equality while the Diala on the other hand want to maintain the status quo. Ultimately, conflict becomes inevitable with attendant negative consequences on the community and greater implications for the entire Igbo nationality. The paper proffers solution on how such conflict can be managed as well how the caste system can be eliminated in its entirety.
\end{abstract}

\section{KEYWORDS: Caste system, Caste conflict, Osu, Diala, Nigeria}

\section{INTRODUCTION}

Social and political pressures arising from divisions on the lines of religion, ethnicity, class, sect and caste have given way for the numerous conflicts the nation is currently experiencing daily. These conflicts have become outstanding features of Nigeria's growth and development.
However, while other forms of conflicts have enjoyed some attention from policy makers, scholars and peace practitioners alike, little or no attention has been given to conflict arising from caste systems in Nigeria. This is due to the fact that oftentimes, caste activities in the country usually go unreported, unaddressed, and even not discussed at the national level. Consequently,

Nneka Sophie Amalu, Department of History and International Studies University of Calabar, Calabar

Yusuf Abdullahi, Department of History, School of Arts and Social Sciences Niger State College of Education, Minna.

Ekong Demson, Department of History and International Studies University of Uyo, Uyo 
there is a dearth of literature on caste conflict in Nigeria and probably why its elimination has also become very daunting. In fact, while so many people are unaware that caste systems do exist in Nigeria, some others who are aware, believe that such institutions have long been abolished and discarded. Unfortunately, caste groups exist and are still very much alive.

For instance, in some part of Northern Nigeria, the caste system is evident. "In the Kamwe community of Michika Local Government Area of Adamawa system, caste system does exist as the race is broadly classified into "Melie and Kaligyi" (Charles, 2021). The Melie who are farmers are at the top of the caste system while the Kaligyi who are blacksmiths are at the bottom. Marriage between the two caste cannot take place. The Melie people cannot eat and drink with the Ka-ligyi. In spite of their status in the community, the Ka-ligyi play certain roles such as calabash decoration, playing music at weddings, washing dead bodies, carving sculptures for religious purposes and weapons manufacturing (Charles, 2021).

Amongst the Igbo of South-east zone of Nigeria, the caste system exists with the people divided into Diala and Osu castes (Amalu, 2018b, p.107). The Osu caste institution is perhaps among the world's longest surviving status discrimination as that of the Indian caste system; and it is believed to be as old as Igboland itself (Onwubuariri, 2016, p.55). The Osu caste system is a tradition that has been handed over from one generation to the other and has not been influenced to a great extent by westernization, Christianity, civilization, advancement in science, globalization or even democracy and the human rights culture; the people continue to give strict observance or face dire consequences. Mgbada (2016, p.351) argues that "of all the customs of Igboland and perhaps Africa at large that Europeans considered repugnant to natural justice, equity and good conscience such as twin killing and extra judicial killing of thieves, the Osu caste system has been the most obstinate in resisting extermination." While claiming that the caste system appears to be the most fundamental and unshakable, he states that "it is fundamental because it is almost aboriginally attached to the traditional system of people-making the necessary distinction between those "free" and "properly" born with legitimacy into the society and those regarded as "illegitimate" by virtue and circumstance of their birth or arrival in the society or, indeed, ultimately by circumstance of their being dedicated to one god or the
other"(Mgbada, 2016, p.355) This distinction has resulted in the struggle between the Diala and Osu over land and economic trees, public properties and community allocations, as the former always assumes superior position over the Osu whom they regard as inferiors. This situation has led to several conflicts between the two groups. While it is evident that the caste system still exists in Nigeria, the conflict between the Osu and Diala will serve as point of reference for analyzing caste conflicts in Nigeria.

Since the origin of caste, conflict between caste groups have been inevitable. Amadi and Obomanu (2016) assert that in recent decades, Osu caste conflict among the Igbo has become more pronounced, violent and widespread to the extent of threatening the peace and unity of the Igbo ethnic nationality. This kind of discrimination has caused great deal of communal conflict between the Osu and Diala in Igboland. In various Igbo communities such Umuode, Umuawuka, Eziama, Emii, etc., clashes and conflicts as a result of the Osu caste system have been experienced over the years. The causes of the conflicts have centered around struggle over economic resources (land, trees) and public properties and community misallocations, the consequences have become enormous ranging from massive loss of lives and properties, to economic and occupation dislocation, rural-urban drift and insecurity in communities where they are practiced with further implications for the immediate society and the Igbo nation at large.

In relations to abolition, the Osu caste system has resisted all measures of elimination thrown at it. It would be recalled that a bill-the 1956(Nigerian Eastern Assembly, 1959) Osu Billlegally abolished the system before independence and even after independence, various Eastern administrations (e.g late Dr. Sam Mbakwe's Nigeria Peoples Party's (NPP) civilian regime in 1979 Imo State, late Air Commodore Emeka Omeruah's military government (19851987) of the old Anambra State) tried to ban the Osu caste system, but to no avail (Igwe and Akolokwu, 2014). Although, some communities have taken it upon themselves and successfully eliminated the caste and integrated the people into the larger community, others are still practicing it silently. In corroboration, (Mgbada, 2016 , p. 361) stated that "in maximum secrecy, every Igbo man maintains a clear distinction between the Diala and Osu". However, religious bodies, human rights agencies and activists, academics and the civil society, as well as wellmeaning Igbo people have also joined in the 
campaign against this dehumanizing system, yet the feelings and superstition still lingers in the heart of some people and is spreading persistently to the younger generation. Certain actions must be taken to stop the caste system mentality as well as raise a generation that will not be caste-unconscious, but rather promote equality and justice which "involves lawfulness and fairness, equitable distribution of goods and services" (Ezedike and Ariche, 2019, p. 133). Thus, it is within this background that the paper examines caste conflicts in Nigeria with focus on the Osu/Diala conflict with the intention of proffering solutions for conflict prevention and management as well as total elimination of the caste systems in Nigeria.

This work is hinged on the frustration-aggression theory which attributes conflict to frustration. According to the theory, aggression is caused by blocking or frustrating a person's efforts to achieve a goal (Dollard, Doob, Mower and Sears, 1939, Berkowitz, 1989). It then means that a frustrated person who could not achieve his desires goals may likely inflict his aggression on the society. In this context, the Osu people have for long been denied their rights and full participation in various activities. Many of them have goals they wish to attain, but the Osu caste system has frustrated such ambitions. Also, the Diala trying to maintain status quo and imposing the submissive position on the Osu people, has generated resentment, frustration and aggression when the Osu constantly try to reject such inferior position. Hence, conflict and violence becomes imminent as a result of these frustration and aggression.

\section{CONCEPTUAL ANALYSIS \\ Caste}

Caste is a term derived from the Portuguese word 'Casta' meaning breed, lineage or race (Chaudhry, 2013, p.56). Defining the term 'caste' itself is difficult than thought to be. Caste represents any social system or set of principles that divides a society according to class distinction based on hereditary, wealth, occupation, position or religion. Agada (2004, p. 30) states that "the basic features of the caste systems are that groups under this system are fixed and closed in order of superior and inferior groups; members are grouped at birth and remain there for life as there are no provisions for social mobility." In other words, a caste is a hierarchy of social order that one is born into with no chance of changing group membership.

\section{Caste conflict}

Conflict has been defined by various scholars and peace practitioners. It is a term that has been described according to Coser (1976, p.8) as "a struggle over values and claims to secure status, power and resources in which the aim of the opponents are to neutralize, injure and eliminate their rivals". "Conflict is basically when individuals or groups struggle over certain goals" (Amalu, 2018a, p.98). On the other hand, caste conflict generally refers to a fight, struggle, collision or clash of opponent caste groups. It can also refer to a clash by opposing caste groups over resources, position, power and recognition with the intent of causing harm and even death to their opponents.

\section{The Osu caste system}

The Osu are basically slaves offered as sacrifice to gods or idols in Igboland. For llogu (1974, p.123) described the Osu as a "slave of the deity dedicated to perform some menial functions which may include sacrificial functions." The word Osu in Igboland simply means a belief system, a traditional and religious belief that certain people should be discriminated from others. It is a name that is given to slave, untouchables and outcasts" (Onwubuariri, 2016, p.59).

On the other hand, Diala is construed to be religious and almost exclusive so. Just as the Osu has religious connotations in terms of dedication, for the Diala, it is like dedication to the earth goddess. Otherwise called Amadi, Nwa, and Nwamu, the Diala are people regarded as the 'sons and daughters of the soil' or 'freeborn'. Agunyai and Etembo (2017, p.16) posit that they are regarded as "the superior human beings while the Osu are less humans." A Diala is that free born in Igboland who suffers no discrimination by virtue of the accident of his birth. His ancestors were perceived as being unpolluted and free as they were not sacrificed to any god or deity. He might be poor economically but he is regarded highly, status wise (Uguwlebo, 2011, p. 179).

\section{Osu and Diala caste conflict}

The fact that Osu caste system breeds division, conflict and communal wars among the Osu and Diala castes has well been established in various literature. However, there seems to be a paucity of literature examining these conflicts, taking into cognizance the causes and consequences; hence the purpose and importance of this paper. These conflicts are discussed below: 


\section{Oruku Community Conflict}

Oruku Community in Nkanu East Local Government Area of Enugu State is made up of three villages, Umuode, Umuchiani and Onuogowo. Since time immemorial, there had been a balance of power among the three. They lived in peace, as brothers from same parents. The custom and tradition governed and guided the people and decision making was done by the three clans According to the Centre for World Indigenous Studies (2021) In 1976, Oruku community drew up a constitution of chieftaincy by which the stool was to rotate amongst the three clans. The rotatory system was already established even before the constitution was draw. However, it was under this constitution that Chief Nwatu Okenwa became the first traditional ruler of Oruku in 1976. After his death, a supposed review of that rotational constitution was drafted devoid of the knowledge of the community. Engr. Raymond Okenwa, brother to the deceased, became the sole administrator of Nkanu LGA and communicated with the then Chairman of the Oruku Development Council, Mr. Felix Nwatu from Umuchiani to install him as the traditional ruler. This did not go down well with the people. The Umuchiani as a way of reconciling with the Onuogowo than fighting to have their son ascend the throne of the 1976 rotation agreement, openly campaigned the idea that the Umuode people are slaves who have no claim whatsoever to the throne. They then imposed His Royal Highness lgwe Cornelus Nomeh on the people based on the 1987 "merit" but his also satisfied the 1976 rotational provisions. By this agreement, Umuode was excluded from ascending the throne. (CWIS, 2021; Dike, 2002; Amadi and Obomanu, 2016).

With their new ascribed status as Osu, the Umuode had little or no social interaction with the other two clans. Amadi and Obamnu (2016, p.7) stated that "the other communities had a separate market and placed a fine of N1000 (One thousand Naira- about $\$ 10$ dollars) on any community member that buys or sells to the Umuode community."

On the $9^{\text {th }}$ of October, 1995, at the reception of Professor. Barth Nnaji, (a world acclaimed professor of Robotic Engineering from Umuode) who received an international award and came down to Nigeria to become a federal minister of Science and Technology under Chief Ernest Shonekan's Interim National Government which held in Professor's compound, armed Oruku youths invaded the reception and drove the guests, while the awardee narrowly escaped them with the help of police officers (CWIS, 2021). Nine Umuode people were captured and later murdered, while their women and girls were raped. Their houses were looted and vandalized as well as their farms and crops. This incident combined to fuel the emergence of caste-induced conflicts on an unprecedented scale and manner including several decades of cultural exclusion, marriage relationships and traditional positions which fueled strong feelings of discrimination and stigmatization among the Osu (Amadi and Obomanu, 2016, p.7). Dike claims that the people of Umuode have waged wars against this system with about five major conflict since 1995, and many lives have been lost and properties destroyed (2007, p.18)

"Due to the recurrence of this conflicts, several investigations were carried out and panels setup, the Umuode community was granted an autonomous status on June $24^{\text {th }}, 1998$ and published in the Enugu State Autonomous Communities Edict, 1999(Edict No.1 of 1999). Consequently, the Umuode people were moved to a new community carved out of land legitimately owned by a neighboring community but still claimed by the Oruku community. The government formally acquired the land to implement the autonomous community of Umuode in the interest of peace" (CWIS, 2021),

The CWIS (1999) stated that on $22^{\text {nd }}$ February 1999, Umuode people were moving to their new land to establish their homes, but this angered the Oruku people as their intention was just to eliminate the Umuode people. After several attempts of suppressing them failed, they resorted to force. The Oruku people armed themselves and attacked the Umuode people, killed and burnt their properties in both the Oruku and their new community. Umuode people who survived had to flee from both Oruku community and their new settlement and had been living in most poor conditions. As a result of this, many Umuode people were murdered, others escaped with gunshot wounds into neighboring communities. It is said that over hundred and fifty persons-including women and children were taken hostage for five days without food and water in a detention camp in Oruku. However, the police raided the place and the people were released. Though some arrests were made by the police, they were said to be released and the case closed. It is clear that people who were once indigenes and land owners now became outcasts, refugees and strangers in their own land (Dike, 2007, p.49). In April, 1999 the then Governor of the state was said to have annulled 
the autonomous status given to the Umuode people on the grounds that it was not acceptable to their neighbors. Also, giving them a separate community would give room for other Osu groups to petition for autonomy in the state (Amadi and Obomanu, 2016). The Commissioner for Special Duties in the State, Mr. Maurice Ede (from Umuode), was allegedly dismissed because he even protested the way the Enugu State handled the crisis (Dike, 2007).

\section{Eziama community conflict}

Eziama is a town in Mbaitoli Local Government Area of Imo State, South-eastern Nigeria. It is about 18 kilometres to the city of Owerri. The town is strategically located as it shares common boundaries with four other Local Government Areas in Imo State. Here, conflicts between the Diala and Osu have been witnessed severally. The Osu complained under the administration of Osita Opara, of which the administrator set up a panel of inquiry. Unfortunately, nothing was heard of the panel nor the investigation. Umahi (in Amadi and Obomanu, 2018, p.8), claimed that the Osu resorted to newspaper publication. Some people were writing and calling on the then Governor, Ikedi Ohakim, to compensate the Osu, but nobody ever come to their aid.

In 2009, the Osu people were attacked by the Diala from Umunya, neighboring community. Those attacked lost both their property and money. Their houses and town hall were burnt down and the transformers destroyed to cut off power supply in the community. In this case as posited by Amadi and Obomauu (2016, p.8) "Chief Christopher O. Ezeh, Chairman of Eziama Development Zone, wrote a letter to the State Government and stated that one of the victims, "Mr Nicholas Iwumezie, died of a heart failure as nothing was left in his shop, his wife became a hopeless widow. The dead man was deposited at the mortuary. On the day of his burial, the mob (attackers-Diala) seized the corpse but for the intervention of one Rev. Father Emmanuel Oparaugo of Stella Maris Catholic Parish, Orodo, who caused the release of the corpse."

Still in the same community, the then governor, Dr, Sam Mbakwe decided to erect a pipe borne water, but before the water could be used, they were rumors that the water was to be erected on Osu land and consequently the project was abandoned. The reason behind this was the Osu are seen as unclean by the Diala and that if the pipe borne water was to be erected in Osu land, therefore the water would be contaminated unfit for drinking by the Diala.
Umuaka Community Conflict

The categorize one of their ten villages Osu. Other minor lower caste groups found in many kindred are given the pejorative lgbo expression of Ndi ejiri goro ihe, meaning those who are sacrificial lambs to the gods (Mezie-Okoye and Asike 2019, p.89). In the late 1980s, the Osu people could not take it anymore, there were scuffles between the Diala and Osu sections of the community. The Osu people physically assaulted a couple of women from the Diala section of the community, with the intention of transforming the women to Osu so that the Diala will reject them (Dike, 2007, p. 18). The action would also give them the taste of the pains and humiliation of the Osu status. It was said that the Diala reacted with force and violence. And around September-October, 2003, there was riot in the "Osu" section of the community because of a, misunderstanding among the people over a name-change. According to Dike (2007, p.54), "a group of people in Amafor believed that the old name, which identifies them as Osu was bringing them ill-luck and bad image and, therefore, wanted the village to adopt a new name and riots ensued when they could not agree on the name. A couple of people sustained injuries and local shops were looted; Obinwanne is its new name." Also, there have been a restriction on them from marrying Diala people and this did not go down well with the people, hence violence was inevitable.

\section{Other Conflicts}

In Amawbia-Awka community in Anambra State, there have also been intercommunal crisis among the Osu and Diala. In the 1980s, in Ifakala community of Mbaitoli Local Government Area of Imo State, there was no good source of water supply and the nearest stream in the area is about eight kilometers away (Dike 2007, p. 51), a water project was abandoned because the Diala claimed that the project was located on Osu land. In Awo-Omamma, there is marital discrimination against the Osu and this has mostly been responsible for the occasional conflicts between the Osu and Diala. a (Ubaka and Ugwuja, 2014, p.299). It will be no accident, that some of the most erogenous cases of caste conflict in Igboland have been incited by Osu men eloping with non Osu women. In the clans of Umuawuka and Emii in Owerri LGA, Imo state, communal clashes between the two castes have been recorded (Dike, 2017, p. 54). In fact, over 60 of such incident have been reported in Imo State alone, since 1979 (Dike, 2007, p. 18). 
Corroborating this is an interview with an indigene from Mbaitoli LGA, Mr. Emmanuel, who commented on the prevalence of the OsulDiala conflict in Imo State as thus "of all the states in Igboland, Imo state is where the Osu has a very stronghold till date. I don't think the way the Osu and Diala fight here is like that in other states."

\section{Causes of the Osu/ Diala conflict}

There are several reasons for the tension between the Osu and Diala caste. Notwithstanding the location of the caste based conflicts, its basic characteristics are the same (Boorah, Targat and Mishra, 2019). Corroborating this is Narula, (1999, p.29), who avers that "whether caste clashes are social, economic or political in nature, they are premised on basic principle and any attempt to alter village customs or to demand for land, increased wage or political rights leads to violence and economic retaliation on the part of the most threatened by the changes in the status quo. The major causes of the Osu/Diala conflict vis a vis other caste conflicts are as follows:

Need, greed scarcity and increase in land value and economic resources like palm trees, etc, are common causes of caste conflicts. Land is an asset and most important resource in any lgbo community. In places where the caste system is practiced, only the Diala have guaranteed access to community land but the Osu remain landless. In confirming this, Apeh and Opata (2009, p. 943) avow that "...the freeborn trace their lineage to the founding ancestors of the village and have an organic relationship with the land as well as an inviolate right to its use. The Osu do not enjoy such rights."

Sharing or using communal or public properties is one of the major causes of the caste conflict. Public properties such as water taps and tanks, markets, community halls and buildings and seating in the same seats in church were some of the factors that contributed to the OsulDiala conflict. The Osu are perceived to be contaminated, having body odour, and unclean, hence using the same water tap or tank or any other communal property with the Osu means it will be contaminated.

For the Diala, when the Osu (lower caste) do not accept the submissive role that the Diala expect of them, it generates resentment, as they (Diala) see traditional communal relations strengthened by the Osu subservience, being eroded. In confirming these situations is (Boorah et al., 18) who posited that "the conjunction of the lower caste demand for greater equality and upper class reluctance to acquiesce to such demand leads to conflict."

However, it is the position of this paper that the major factor fueling the Osu/Diala conflict as well as caste conflicts in general centers around discrimination and human rights violations of the lower caste (Osu) by the higher caste (Diala). "Human rights are legal entitlements which every citizen must enjoy without fear of the government or fellow citizens" (Amalu, 2019, p.134). The Osu rights to life, rights to marriage, rights to associate, rights to land and to own property, rights to partake in both political, social, cultural and religious activities of their communities, yet these rights are denied of them. If only caste systems do not discriminate or violate fundamental human rights of the group considered lower or inferior, most of the conflicts between caste groups would be prevented, managed or avoided. Unfortunately, caste systems in Nigeria and across the globe are not wired in that manner; in fact, the purpose of caste groups are to deliberately restrict some groups of people usually considered as outcast, inferior, lower, second class citizens, unclean, untouchable from enjoying basic rights and privileges and restricting them to certain roles and functions of the society where it is practiced. In the context of the Osu caste system, the people branded Osu have no right to own lands and economic resources; no right to use communal properties; no right to partake in certain political, social, religious and cultural activities of the community. Ultimately, such situation will breed anger, hatred, frustration, inferiority complex, aggression, depression, anxiety and tension, consequently, conflict and violence becomes unavoidable between the caste groups.

\section{Consequences of the Osu/Diala caste conflict}

The consequences of most conflicts are common and far reaching. It ranges from massive loss of lives (Osu, Diala, and non-lgbo) to destruction of public and personal properties. Economic dislocation is another serious consequence of conflict. Markets, shops, offices and work places are destroyed and looted. Thus most people are out of jobs with no means of survival, business no longer thrive as goods are no longer available. Physical and psychological/mental problems such as heart attack, wounds, bone fractures, depression, stress, anxiety, arises as a result of conflict. Amalu (2020, p.98) states that "these problems can become chronic or recurrent and lead to substantial impairment in an individual's 
ability to take care of his everyday responsibilities." There is a loss of farmland and produce leading to temporary food insecurity and shortages massive displacement from their original homeland to migration of people to other areas for fear of elapsed conflicts.

Recounting his ordeal in Eziama community through a phone interview, Mr. Obinna Ugo stated that; "...my cousin died as a result of the conflict between the Diala and Osu in 2009. Many people also lost their loved ones too. My cousin is from Edo, her father married my mothers' sister. She came visiting after her national service was over some three weeks past, only for her to come and die here. She was not an Osu or Diala but lost her life as a result of this stupid problem."

Again in Eziama, Amadi and Obomauu (2016, p.8) narrated that "chief Christopher O. Ezeh, Chairman of Eziama Development Zone, wrote a letter to the State Government and stated that one of the victims, "Mr Nicholas Iwumezie, died of a heart failure as nothing was left in his shop, his wife became a hopeless widow." In an interview with another indigene of Umuode, Mr. Micheal Amadi, who wept bitterly as he claimed that the Diala looted his shop where he sells plumbing materials and burnt it down and took away the money they found inside."

It is clear that when there is an outbreak of conflict and violence, it affects those involved and those not involved. People of non-Igbo stock who may be residing in those communities or who came for one function or the other have also become victims of the OsulDiala dichotomy. Hence the need for a national action towards its elimination.

\section{Implications of the osu caste system for the Igbo people}

It is established that the Osu caste system and the conflicts arising from it has severe negative consequences. It generates a lack of trust and unity among the Igbo. Mgbada (2016, p.352) maintains that "the natural tendency to discriminate against some individuals or lineages or families seems to be largely responsible for the lack or absence of unity among the lgbo people. The institutionalized discrimination in the caste system breeds a high degree of discord and disunity." The Osu caste system over the years has developed parochial feelings and made the Igbo people unduly conscious of their own caste. Many a time, caste interest was given priority over national interest.
The Osu have famous and high-ranking persons from all works of life with the essential ingredients for communal development, but since the community abhors them, they rarely contribute to the development of the community. Onwubuariri (2016, p.34) adumbrates that "the isolation of the Osu from the freeborn socially can hamper the socio-economic well-being and development of the society, as the Osu may decline bringing in their own quota in the economic and social sphere." Again, the Osu practice in Igboland greatly affects the ability of the people to cultivate the benevolence of social bonding needed for development. Indeed, "no nation can develop where insecurity is prevalent" (Amalu 76), hence, growth and development of Igboland and the entire nation as a whole are threatened by the Osu/Diala conflict.

It also hampers the prospects of communal selfhelp development projects (CSH-DP) in Igboland" (Ubaka and Ugwuja, 2014, p. 310). This could also be the reason why the Igbo nation has not yet produced a president for the nation because a people who are internally divided can never be united as a group to pursue any goal externally. No Osu will participate politically or vote for a government or an individual that will segregate or marginalize and dehumanize them. Also, the political system should be based on who deserves the post or who can represent the people, it should not be based on caste (Osu or Diala). The Igbo are so enlightened to allow this backward and negative tradition to affect them in their communities in the $21^{\text {st }}$ Century. Segregation or discrimination of this kind will only breed social disharmony and undermine the cohesiveness in Igboland.

\section{CONCLUSION}

Caste conflict are rife in Nigeria, despite the low attention given to it by the media, academics and policy makers. However, the Osu caste system has shown to breed conflict and violence among the Osu and Diala. The basis of this conflict lies in the human rights infringement that comes with the Osu caste system. The consequences of the conflict were massive loss of lives, destruction of public and personal properties, rural-urban drift and rural insecurity. The work concludes that caste conflicts can be prevented, managed and even avoided if the caste system can be eliminated in its entirety; physically and psychologically.

The Igbo need all-hands-on-deck if they must actualize their dreams of producing a president in the next 2023 presidential elections. The 
politicians in the region can set aside some time for some campaign and awareness, demonstrating that their inability to have an Igbo president is because of the internal social divide where the Osu cannot contribute in numbers and ideas politically.

A psychological problem needs a psychological solution. The Osu caste system has a psychological dimension, whereby the Diala think that associating with an Osu will bring negative consequences upon their lives. It has eaten deep into the fabrics of the minds of some Diala, hence, there must be psychological abolition of the system as well as counselling.

Religious bodies must continue in their campaign by preaching equity and equality in their sermons. The social media has become one of the most powerful tools in fighting for equality; it should be strengthened to create further awareness against the system.

\section{INTERVIEWS}

Mr. Obinna Ugo, Eziama Community, Imo State, Face interview, June 3, 2019.

Mr. Micheal Amadi, Umuode Community, Enugu State, Telephone Interview, June 9, 2019.

Mr. Emmanuel Emmanuel, Mbaitoli LGA, Imo State Face Interview, June 4, 2019.

\section{REFERENCES}

Apeh, A. and Opata, C., 2009. Social Exclusion: An Aftermath of the Abolition of Slave Trade in Northern Igboland, Nigeria. pp 941-958. In: C. Grasso and S. Casper (Editors) William and Mary Quarterly: A Magazine of Early American History and Culture. LXVI(4). Omohundro Institute of Early American History and Culture, 1019p, Virginia.

Amalu, M. N., 2020. Psychological Impact of COVID-19 Pandemic on Mental Health of Students in Nigeria: The Professional interventions. Prestige Journal of Education. Vol.3 (1), 96-104.

Amalu, N. S., 2019. The Role of the National Human Rights Commission in Post Conflict Situation in Nigeria. AFRREV IJAH: An International Journal of Arts and Humanities, 8(1), 132-142.

Amalu, N. S., 2018a. The Role of Faith-based Organization in Post Conflict Reconstruction. The case of Justice,
Development

and

Peace

Commission (JDPC), 1999-2016. International Journal of Integrative Humanism. 8(1): 97-106, Ghana.

Amalu, N. S., 2018b Indigenous Symbols and their Communicative Implications for Conflict Management and Peacebuilding amongst the Igbo, Nigeria 1900-2016. International Journal of Integrative Humanism. 8(1): 107-116, Ghana.

Amalu, N.S., 2018c Food Security and Nigeria's Development Since Independence: Opportunities and Constraints. International Journal of Public Administration and Management Research (IJPAMR). 4 (4) 69-81, 2018, Nigeria.

Berkowitz L., 1989. Frustration-Aggression hypothesis: examination and reformulation. Psychological Bulletin, 106 (1), 59-73.

Boorah, V., Targat, A. and Mishra, V., 2009 Conflict, Caste and Resolution: A Quantitative Analysis for Indian Villages. Munich Personal RePEc Archive. Indian Institute of Dalit Studies, Monk Prayogshala.

Centre for World Indigenous Studies CWIS, 2021. Slavery, castesism (OSU) and displacement:

The Experience of the Umuode Community in Enugu State Nigeria. Cwis.org. Retrieved 7/6/2021

Charles, V. The place of Blacksmith Ka-ligyi in Caste system in the Higgi Kamwe of Michika LGA, Adamawa state. www.unihildesheim.de Retrieved 6/6/2021

Chaudhry, P., 2013. Caste as an Institutionalized System of Social Exclusion and Discrimination:

Some evidences. International Journal of Gender and Women's Studies, 1(1):5663

Coser, L., 1976. The functions of social conflict. Glencoe: Free press. 
Dollard, J., Doob, L. W., Miller, N.E., Mowrer, O. $H$. and Sears 1939. Frustration and aggression.

New Haven. CT US: Yale University Press.

Dike, V., 2007. The Osu caste discrimination in Igboland: Impact on Igbo culture and civilization. IUniverse Publishers, 150pp.

Dike, V., 2002. The Osu caste system in Igboland discrimination based on descent. 61st Session of the Committee on Elimination of Racial Discrimination (CERD) held in London from 8-9 $9^{\text {th }}$ August 2002, 22p.

Ezedike, E. and Ariche, C., 2019. Ethical issues in traditional herbal medical practice in Nigeria. International Journal of Humanities and Innovation (IJH) 2(4):129-135.

Ilogu, E., 1974. Christianity and Igbo Culture. Brill Archive, 262p, Netherlands.

Mgbada, C. O., 2016. Osu Caste System and the Problem of Slave Integration in Igboland: The Abakiliki Experience, pp 351-370. In: D. Imbua, C. Ogbogbo, S. Effah, and Y. Ochefu (Editors) Okon Uya @70: Issues in Historiography, Nation-Building and the African Diaspora. 585p. Aboki Publishers, Markurdi.
Narula, S., 1999. Broken People: Caste Violence against India's "Untouchable", Human Rights Watch, NewYork,

Onwubuariri, F., 2016. "Appraising the Osu caste system in Igboland within the context of complementary reflection" IGWEBUIKE: An African Journal of Arts and Humanities, 2 (4):54-93.

Orji, M. and Anyim, B., 2016. Osu in Igbo Tradition and Journey Towards Civilization: The Case of Umuocho Kindred in Amagu Ishiagu ivo, Ebonyi State. CACH Journal of Humanities and Cultural Studies 1, 123-136.

Ubaka, K. and Ugwuja, A., 2014. Ohu/Osu Caste System in Awo-Omamma and Nsukka Communities: Impediments to National Integration. UJHIS, 4 (1):290-314.

Ugwulebo. E., 2011. Singing the Nunc Dimitis of the Osu Caste System in Igboland, Expectations from the Religious, pp 179195. In: T. Okere (Editor) The Church and Igbo Society, 2(10) Whelan Research Academy, 400p. Owerri, Nigeria. 